\title{
EVALUASI PENGGUNAAN APLIKASI SISTEM KEUANGAN DESA (SISKEUDES) DI NAGARI KAYU TANAM KECAMATAN 2X11 KAYUTANAM
}

\author{
Wahib Assyahri ${ }^{1}$, Mercya Vaguita ${ }^{2}$ \\ ${ }^{1,2}$ Magister Administrasi Negara, Universitas Negeri Padang, Padang, Indonesia \\ Email:wassyahri.wa@gmail.com,mercyavaguita@gmail.com
}

\begin{abstract}
ABSTRAK
Aplikasi Siskeudes ini merupakan suatu sistem yang dikembangkan oleh BPKP dalam meningkatkan kualitas tata kelola keuangan desa. Pemerintah Padang Pariaman sudah menetapkan Siskeudes untuk diaplikasikan namun pada kenyataannya masih banyak nagari yang ada di Kecamatan 2 x11 Kayutanam khususnya nagari kayu tanam ini mengalami kendala dalam mengaplikasikannya. Penelitian ini bertujuan untuk mengevaluasi pelaksanaan aplikasi Siskeudes di Nagari Kayu dalam mewujudkan pengelolaan keuangan nagari yang transparan dan secara akuntabel. Penelitian ini merupakan penelitian kualitatif dengan menggunakan pendekatan deskriptif. Data penelitian didapatkan melalui observasi, studi dokumentasi, dan wawancara secara mendalam, kemudian dianalisis dengan tiga tahapan untuk penelitian ini. Hasil penelitian menunjukkan bahwa (1) Penerapan Aplikasi Siskeudes di Nagari Kayu Tanam sudah cukup baik dalam penggunaannya, dilihat dari aspek efisiensi, efektif, dan kesesuaian dalam aplikasi tersebut melalui tahap perencanaan dan tahap pelaksanaan, sedangkan belum efektif dan belum ada kesesuaian pada tahap pelaporan dan tahap pertanggungjawaban, tetapi masih banyak kendala yang dihadapi dalam pelaksanaannya, yaitu; kurangnya sumber daya manusia yang ada; pelatihan-pelatihan dari pihak kabupaten belum maksimal; keterlambatan dalam penyusunan laporan pertanggungjawaban; dan partisipasi masyarakat yang masih kurang. (2) Faktor-faktor penyebab kendala yang ditemukan dalam penggunaan sistem keuangan desa tersebut, yaitu adanya kesalahan teknis, adanya gangguan lingkungan, dan adanya kelalaian manusia. Berdasarkan hasil penelitian dan pembahasan, dapat disimpulkan bahwa penggunaan aplikasi sistem keuangan desa (Siskeudes) di Nagari Kayu Tanam Kecamatan $2 x 11$ Kayutanam sudah cukup baik diterapkan tetapi dalam pelaksanaannya masih ada kendala-kendala yang terjadi.
\end{abstract}

Kata Kunci: Evaluasi, Keuangan Desa, Siskeudes, Sistem Informasi Manajemen.

\section{PENDAHULUAN}

Setelah diberlakukan UU RI Nomor 6 Tahun 2014 Tentang Desa (Diamantina 2016). Desa kemudian memiliki kewenangan sebagai daerah otonom. Desa diberikan peluang untuk mengelola tata pemerintahannya, termasuk dalam pelaksanaan pembangunan masyarakat desa. Pengelolaan keuangan desa ini mewujudkan tata pemerintahan yang baik, sesuai Permendagri Nomor 113 tahun 2014 (Pemerintah Republik Indonesia 2014) pasal 2 secara partisipasi, akuntabilitas, transparansi, dan keadilan. Aplikasi ini digunakan untuk membantu pekerjaan pemerintah desa dalam mengelola keuangannya mulai dari perencanaan, pelaksanaan, penatausahaan, pelaporan 


\author{
NAKHODA: JURNAL ILMU PEMERINTAHAN \\ Edisi Juli-Desember 2019 Tahun Volume: 18 Nomor: 2 \\ ISSN : 1829-5827 | E-ISSN : 2656-5277 \\ DOI : https://doi.org/10.35967/jipn \\ https://nakhoda.ejournal.unri.ac.id/index.php/JIPN
}

sampai dengan pertanggungjawaban keuangan desa. Aparatur desa di seluruh Indonesia khususnya di Nagari Kayu Tanam Kecamatan 2x11 Kayutanam mempunyai tugas mengelola keuangan desa seharusnya sudah menggunakan aplikasi Siskeudes yang dapat membantu pelaksanaan tugas tersebut mengingat aplikasi tersebut sudah diluncurkan pada tahun 2015.

Berdasarkan penelitiannya Eka Puspita, Dian (2019), menyatakan bahwa di Desa Nogosari dalam melakukan penerapan aplikasi siskeudes telah menjalankan secara menyeluruh dan dalam proses pengimputan dan pelaporannya sudah melakukan proses pertanggungjawaban yang sudah relevan sesuai dengan Permendagri No. 113 Tahun 2014 dan dalam menjalankan aplikasi tersebut sudah terstruktur dengan baik. Sedangkan menurut Lengkong and Tasik (2018), bahwa Kabupaten Minahasa memiliki skor tertinggi dengan nilai 2,75, diikuti Kabupaten Minahasa Utara dan Minahasa Selatan dengan skor 2,54 dan 2,53. Pada dimensi pembangunan sarana prasarana desa, terlihat bahwa dana desa cenderung difokuskan untuk pendanaan pembangunan Sarpras transportasi. Pada dimensi pemberdayakan masyarakat, desadesa yang diteliti kurang mendanai program pemberdayakan masyarakat.

Pada penelitian lain membuktikan bahwa aplikasi siskeudes belum maksimal dalam pelaksanaannya, menurut Novirania (2018), bahwa aplikasi Siskeudes dalam pelaksanaan masih terdapat masalah yang terjadi adalah kurangnya sumber daya manusia sehingga SDM masih banyak memiliki kekurangan tiap-tiap desa. Kemudian, terdapat memasukan data dan hukum ini masih belum diterima penjelasannya. Jadi, penerapan aplikasi Siskeudes ini belum tepat dalam pelaksanaannya dan desa ini masih menggunakan secara manual. Penelitian selanjutnya Armala, Sari Musfita (2019) meneliti tentang mekanisme pertanggungjawaban Dana Desa dalam kerangka implementasi salah satu agenda dari Nawa Cita Jokowi-JK di desa Berumbung Baru yang diklasifikasikan sebagai Desa Maju dan Desa Tumang yang diklasfikasikan sebagai Desa tertinggal di Kabupaten SIAK, Provinsi Riau. Hasil penelitian menunjukan bahwa terdapat beberapa kesamaan dan perbedaan dalam proses pelaporan dan pertanggungjawaban antara kedua desa yang menjadi poin penilaian terhadap implementasi agenda Nawa Cita Jokowi-JK, diantara adalah mekanisme penyusunan laporan, tahapan pelaporan, dinamika yang terjadi, penilaian terhadap kebijakan.

Pelaksanaan aplikasi Siskeudes di Nagari Kayu Tanam Kecamatan 2x11 Kayutanam ini sudah ada pada tahun 2015, tetapi baru ini diterapkan ditahun 2018 dan saat ini. Menurut Bapak Ali Mukni dalam Ari (2018), bahwa diadakan sosialisasi di Pemerintah Kabupaten Padang Pariaman, dihadiri oleh Camat dan Wali Nagari seKabupaten Padang Pariaman, Ketua DPRD Kabupaten Padang Pariaman, Kajari Pariaman, Kapolres Padang Pariaman, Kapolres Pariaman, Dandim Pariaman, dan Kepala Pemkab Padang Pariaman, dengan mengemukakan bahwa tahun 2017 sekitar 43 nagari pemekaran belum mendapat kucuran dana desa, sedangkan pada tahun 2018 sekitar 43 nagari tersebut telah mendapat kucuran dana desa sehingga dana desa pada tahun 2017 berjumlah Rp. 
50,5 Miyar untuk 60 nagari, maka pada tahun 2018 naik menjadi Rp. 81,9 Milyar untuk 103 nagari dengan rata-rata pernagari sebesar Rp. 795 juta. Ditambah dengan ADD yang diterima dari Pemerintah Kabupaten dengan angka ratarata sebanyak Rp. 785 juta per nagari, sehingga rata-rata untuk nagari ini memiliki pendapatan Rp. 1.5 Milyar pertahun.

Pemerintah Padang Pariaman sudah menetapkan Siskeudes untuk diaplikasikan namun pada kenyataannya masih banyak nagari yang ada di Kecamatan 2x11 Kayutanam khususnya nagari kayu tanam ini mengalami kendala dalam mengaplikasikannya. Berdasarkan hasil wawancara yang dilakukan penulis dengan Lembaga Pemberdayaan Masyarakat Nagari pada tanggal 21 Agustus 2019, menyatakan bahwa laporan keuangan nagari dan pertanggungjawaban pemerintah nagari kayu tanam masih menggunakan manual dan sudah menggunakan sistem keuangan desa yang terkomputerisasi secara online, akan tetapi penerapan sistem keuangan desa ini sering mengalami kendala seperti gangguan jaringan apabila terjadi listrik mati, perangkat yang mendukung sistem tersebut masih terbatas, dan masih mengalami kekeliruan dikarenakan setiap tahun sistem keuangan desa ini mengalami perubahan versi, tetapi penerapan Siskeudes tersebut sudah ada disosialisasi pada tahun 2016 dan tahun 2017.

Berdasarkan latar belakang penulis di atas, maka penulis tertarik untuk melakukan penelitian dengan judul "Evaluasi Penggunaan Aplikasi Sistem Keuangan Desa (Siskeudes) di Nagari kayu Tanam Kecamatan 2x11
Kayutanam". Rumusan masalah yang dikemukakan dalam penelitian ini adalah sebagai berikut:

1. Bagaimana evaluasi penggunaan aplikasi Sistem Keuangan Desa (Siskeudes) di Nagari Kayu Tanam Kecamatan 2x11 Kayutanam.

2. Apa saja kendala dalam penggunaan Sistem Keuangan Desa di Nagari Kayu Tanam Kecamatan 2x11 Kayutanam.

\section{KERANGKA TEORI \\ Evaluasi}

Menurut Mulyadi, Deddy (2016), secara umum evaluasi diartikan sebagai penaksiran, suatu angka, dan nilaian, biasanya kata yang menyatakan usaha menganalisis hasil kebijakan. Dalam arti spesifik, evaluasi informasi suatu nilai dari hasil kebijakan. Fungsi evaluasi ialah menyediakan suatu informasi berguna untuk pihak penentu kebijakan yang diambil berdasarkan evalusi yang telah dilakukan. Tujuan dari evalusi adalah untuk mengetahui tingkat keberhasilan suatu pengguna/kegiatan, menentukan tindak lanjut hasil penilaian dan memperbaiki pertanggungjawaban. Proses dalam melakukan evaluasi kegiatan menurut Wirawan (2011) bahwa evaluasi sebagai riset untuk menganalis dan menilainya dengan cara membandingkan dengan indikator evaluasi dan hasilnya untuk mengambil suatu keputusan. Sedangkan menurut Budi Winarto dalam Usman dan Habib (2016), evaluasi dipandang sebagai suatu kegiatan fungsional. Artinya, evaluasi kebijakan tidak hanya dilakukan pada tahap akhir saja, melainkan dilakukan dalam seluruh proses kebijakan. Dengan demikian, 
evaluasi kebijakan bisa meliputi tahap perumusan masalah kebijakan, program yang diusulkan untuk menyelesaikan masalah kebijakan, implementasi, maupun tahap dampak kebijakan.

Indikator yang digunakan untuk mengevaluasi kebijakan dalam penggunaan aplikasi siskeudes, berdasarkan teorinya Orville F. Porland (dalam Vyara, 2017), yaitu (1) Efisiensi yaitu masukan ke dalam perkerjaan sesuai dengan keluarannya. Program yang efisien ditandai dengan perbaikan program sehingga menjadi lebih murah dan lebih cepat. (2) Efektif yaitu ukuran sejauh mana suatu proses pengembangan mencapai tujuan khusus yang ditetapkan. Semakin tinggi pencapaian tujuan sebuah program maka dikatakan program tersebut semakin efektif. Program yang efektif ditandai dengan perbaikan program sehingga menjadi baik dan lebih aman. (3) Kesesuaian yaitu apakah sebuah program layak untuk dilakukan kesesuaian program salah satu dilihat dari kecocokan atau penempatan atau pelaksanaan program dengan tempat atau sasaran program tersebut. Sedangkan menurut Mulyadi, Deddy (2016), keberhasilan implementasi kebijakan dilihat dari empat indikator yaitu; (1) Komunikasi, menekankan pada setiap kebijakan akan dapat dilaksanakan dengan baik jika terjadi komunikasi efektif terhadap pelaksanaan program dengan para kelompok sasaran. (2) Sumber Daya, menekankan setiap kebijakan harus didukung dengan sumber daya yang memadai, baik sumber daya manusia maupun sumber daya finansial. (3) Disposisi, menekankan terhadap karakteristik yang erat kepada implementor kebijakan/program. (4) Struktur Birokrasi, struktur birokrasi menjadi penting dalam implementasi kebijakan.

\section{Keuangan Desa}

Keuangan desa merupakan semua yang terkait tentang hak dan kewajiban desa yang dinilai dengan uang dan segala sesuatu berupa uang dan barang yang berhubungan dengan pelaksanaan hak dan kewajiban desa tersebut. Menurut Perbub Padang Pariaman Tentang Pengelolaan Keuangan Nagari adalah keseluruhan kegiatan yang meliputi perencanaan, penganggaran, penatausahaan, pelaporan, dan pertanggungjawaban keuangan nagari. Menurut Permendagri tentang asas pengelolaan keuangan desa, yaitu: a) Transparan, yaitu memungkinkan masyarakat untuk mengetahui dan mendapat akses informasi seluas-luasnya tentang keuangan desa, serta membuka diri terhadap hak masyarakat untuk memperoleh informasi yang benar, jujur, dan tidak diskriminatif tentang penyelenggaraan pemerintahan desa. b) Akuntabel, yaitu mempertanggungjawabkan pengelolaan dan pengendalian sumber daya dan pelaksanaan kebijakan yang dipercayakan dalam rangka pencapaian tujuan yang telah ditetapkan. c) Partisipatif, yaitu penyelenggaraan pemeritahan desa yang mengikutsertakan kelembagaan desa dan unsur masyarakat desa. d) Tertib dan disiplin, yaitu pengelolaan keuanga desa harus mengacu pada aturan atau pedoman yang melandasinya.

\section{Aplikasi Sistem Keuangan Desa (Siskeudes) \\ Aplikasi Sistem Keuangan Desa disebut Siskeudes ini berdasarkan BPKP (dalam Welley, Koleangan, and Kawung}


2019) merupakan suatu aplikasi melalui pengembangan Badan Pengawasan Keuangan dan Pembangunan (BPKP) dalam rangka meningkatkan kualitas tata kelola keuangan desa. Dalam aplikasi Siskeudes terbagi menjadi 4 modul, diantaranya yaitu sebagai berikut, yaitu Perencanaan, Penganggaran, Pelaksanaan/ Penatausahaan dan Pelaporan/ Pertanggungjawaban.

Menurut Eko Nugroho dalam Hidayat (2011) faktor-faktor kendala dalam penerapan sistem terutama pada penggunaan aplikasi siskeudes, ada tiga indikator yang digunakan, yaitu: a) Kesalahan teknis, dapat terjadi karena permasalahan-permasalahan perangkat kerasnya, kesalahan dalam penulisan sintak. b) Gangguan lingkungan, dapat berupa gempa bumi, kegagalan arus listrik, api, tempeatur tinggi, debu dan air, kemudian banjir dan angin ribut. c) Kelalaian manusia, yang tidak sengaja termasuk kedalam gangguan lingkungan, karena menggunakan data yang salah, serta menghapus data tanpa sengaja.

\section{Sistem Informasi Manajemen}

Sistem informasi menurut Sutabri (2016) adalah suatu sistem suatu organisasi yang mempertemukan kebutuhan pengolahan transaksi harian yang mendukung fungsi operasional yang bersifat manajerial dengan kegiatan srategi dari suatu organisasi untuk dapat menyediakan kepada pihak luar tertentu dengan laporan-laporan yang diperlukan. Menurut George M. Scott dalam Darmawan, Deni (2013), sifat-sifat dari SIM, yaitu a) sistem yang komprehensif, b) sistem terkoordinasi, c) memiliki subsistem informasi, d) sistem yang terintegrasi secara rasional, e) mengubah data menjadi informasi dengan berbagai macam cara, f) meningkatkan produktivitas, g) sesuai gaya dan karakteristik manajer, h) menggunakan criteria kualitas yang telah ada.

\section{HASIL DAN PEMBAHASAN}

Hasil penelitian tentang evaluasi penggunaan aplikasi sistem keuangan desa (Siskeudes) di Nagari Kayu Tanam Kecamatan 2x11 Kayutanam, dapat dijelaskan sebagai berikut.

Evaluasi Penggunaan Aplikasi Sistem Keuangan Desa (Siskeudes) di Nagari Kayu Tanam Kecamatan Kayu Tanam

\section{Perencanaan}

Tahap perencanaan ini diawali dengan membuat Rencana Pembangunan Jangka Menengah Nagari (RPJMNagari). Berpedoman RPJM Nagari yang telah dibuat, pemerintah nagari membuat rencana kerja tahunan disebut (RKP Nagari). RKP Nagari yang telah disusun akan menjadi dasar pembuatan Rancangan Anggaran Pendapatan dan Belanja Nagari (APB Nagari). Berdasarkan hasil wawancara dengan Ibuk Rina sebagai Sekrertaris Nagari, menyatakan bahwa:

"Aplikasi SISKEUDES ini sangat membantu dalam mewujudkan transparansi dan akuntabilitas dalam pengelolaan APB Nagari ini, mulai perencanaan dengan adanya pengusulan rencana kegiatan pemerintah oleh tiap-tiap korong ini sesuai dengan RPJMNagari Kayutanam Tahun 2018-2024. Selanjutnya disusun RKPNagari Nomor 05 Tahun 2019 tentang RKPNagari Tahun 2019. Aplikasi ini 


\author{
NAKHODA: JURNAL ILMU PEMERINTAHAN \\ Edisi Juli-Desember 2019 Tahun Volume: 18 Nomor: 2 \\ ISSN : 1829-5827 | E-ISSN : 2656-5277 \\ DOI : https://doi.org/10.35967/jipn \\ https://nakhoda.ejournal.unri.ac.id/index.php/JIPN
}

untuk menimalisir masalah yang terjadi dalam pengelolaan keuangan nagari, hal ini menghindari kesalahan ataupun kekeliruan dalam penginputan."

Jadi, setiap kegiatan yang diusulkan masing-masing jorong dan ditetapkan melalui musyawarah nagari sudah efisiensi dalam perencanaan kegiatan nagari yang diusulkan langsung oleh masyarakat. Sebagai gambar di bawah ini merupakan salah satu bentuk musyawarah, yaitu:

Gambar 1.

Musyawah Nagari Limo kaum Tahun 2019

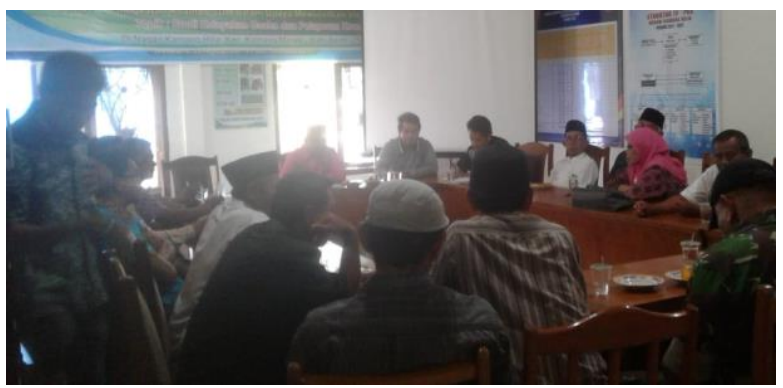

Kemudian, pihak nagari mengundang Bapak Camat 2x11 Kayutanam, Bapak Anggota DPRD Kab. Padang Pariaman, Bhabinkantibmas 2x11 Kayutanam, Bhabinsa 2x11 Kayutanam, Ketua Bamus beserta anggota, Kepala Instansi Kecamatan, Kepala TK/SD/MTS/SMA, KAN, Ketua Lembaga Nagari, Wali Jorong, Tim Verifikasi RKP, Tokoh Masyarakat, Organisasi Kemasyarakatan, Tenaga Ahli Pendamping Desa, Pendamping Desa, Pendamping Lokal Nagari untuk menetapkan kegiatan yang akan dilaksanakan selama satu tahun kerja pemerintahnagari. Hal tersebut sudah efektif dalam proses penetapan usulan kegiatan dalam penempatan anggaran, karena penganggaran ini disusun oleh wali nagari beserta perangkat nagari kemudian bamus nagari yang menyetujui dan menyepakatinya. Selanjutnya, ditetapkan Peraturan Nagari Nomor 02 Tahun 2019 tentang APB Nagari tahun anggaran 2019, lalu diinputkan dalam aplikasi Siskeudes, proses ini sudah sesuai dengan anggaran kegiatan yang diusulkan tersebut diinput secara langsung dalam aplikasi siskeudes dan juga dilakukan secara manual.

\section{Pelaksanaan}

Pelaksanaan realisasi APB Nagari Kayu Tanam tahun 2018 sudah terealisasikan satu tahun anggaran. Kemudian, pelaksanaan APBNag tahun 2019 ini sedang dalam pelaksanaan khusunya dibidang pembangunan. Pada bidang penyelenggaraan pemerintah sudah efisiensi direalisasikan, seperti Pembayaran Hasil Tetap/Tunjangan, Kegiatan Operasional Kantor Nagari, dan Kegiatan Penyelenggaraan Musyawarah Nagari ini sudah direalisasikan sesuai ketetapannya. Terdapat Tim Pelaksanaan Kegiatan (TPK) dan Tim Penerima Hasil (TPH) yang telah ditetapkan sebelumnya, dijadikan sebagai penanggungjawab dalam pelaksanaan kegiatan ini. Kemudian, kegiatan dilaksanakan sudah cukup efektif dilakukan oleh setiap Tim Pelaksana Kegiatan dengan membuatkan SPJ kegiatan dan bukti yang jelas, hal ini digunakan dalam pencairan dana melalui Bendahara Nagari. Pembukuan yang wajib dimiliki Bendahara sudah ada kesesuaian dengan pedoman yang ditetapkan untuk pegangan bendahara nagari, diantaranya yaitu; Buku Kas Nagari, Buku Pajak, dan Buku Bank, Buku Rincian Pendapatan, dan 
Buku Rincian Pembiayaan. Laporan pelaksanaan kegiatan yang dibuat oleh Bendahara ini kemudian disampaikan kepada Sekretaris untuk diverifikasi dan lanjut kepada Wali Nagari. Dalam penerimaan dan pengeluaran anggaran tersebut dipertanggungjawabkan oleh TPK dan TPH, dan Bendahara harus mencatat dan membukukan secara manual dan melalui aplikasi SISKEUDES ini. Sebagai berikut tabel kegiatan pada bidang pembangunan nagari kayu tanam tahun 2019, yaitu;

Tabel 4.1

Kegiatan Pembangunan Nagari Limo Kaum tahun 2019

\begin{tabular}{|l|l|l|}
\hline No. & \multicolumn{1}{|c|}{ Kegiatan } & \multicolumn{1}{c|}{ Lokasi Kegiatan } \\
\hline 1. & Pembuatan Drainase & Pasa Usang \\
\hline 2. & Rehap Jalan Korong & Pasa Usang/Pasa Gelombang \\
\hline 3. & Pembuatan Jalan Usaha Tani & Pasa Usang/Pasa Gelombang \\
\hline 4. & Pemasangan Bronjong Batang Anai & Pasa Usang \\
\hline 5. & $\begin{array}{l}\text { Pembuatan Saluran Irigasi Bandar } \\
\text { Baru }\end{array}$ & Pasa Usang/Pasa Tangah/Pasa Gelombang \\
\hline 6. & Rehap Irigasi Banda Baru & Pasa Gelombang \\
\hline 7. & Rehab Irigasi Banda Pulau & Pasa Gelombang \\
\hline 8. & $\begin{array}{l}\text { Pembangunan DAM DPT Jalan } \\
\text { Tabiang dan Perawatan }\end{array}$ & Pasa Usang/ Pasa Gelombang \\
\hline 9. & Pembangunan Pagar Kantor KB & Pasa Usang \\
\hline 10. & Pengaspalan Jalan Padang Mantuang & Titian Panjang \\
\hline 11. & Pengaspalan Jalan Padang Kabau & Pasa Gelombang \\
\hline 12. & Pembukaan Jalan Baru & Pasa Gelombang \\
\hline
\end{tabular}

Sumber: RKJM-Nagari Kayu Tanam Tahun 2018-2024

\section{Pelaporan}

Tahap pelaporan ini, pemerintah nagari kayu tanam sudah bertanggungjawab dalam laporan kepada Bupati melalui persetujuan Bamus nagari selaku perwakilan masyarakat. Sesuai dalam RKP Nagari Tahun 2019 , berdasarkan isi laporan kegiatan nagari tahun 2018 telah direalisasikan. Pada tahap pelaporan ini sudah cukup efisien dan efektif melalui spanduk yang dipasangkan dekat depan kantor Wali Nagari di Kayu Tanam, spanduk ini merupakan salah satu bentuk keterbukaan pemerintah nagari dalam laporan keuangan nagari kayu tanam kepada masyarakat. Tetapi pada realisasinya, masih ada juga yang belum sesuai antara kegiatan yang dilaksanakan dengan anggaran yang ditetapkan. Sebagai berikut gambar spanduk yang ada di depan Kantor Wali Nagari Kayu Tanam, yaitu:

Gambar 4.2 Musyawarah Nagari Kayu Tanam 2018

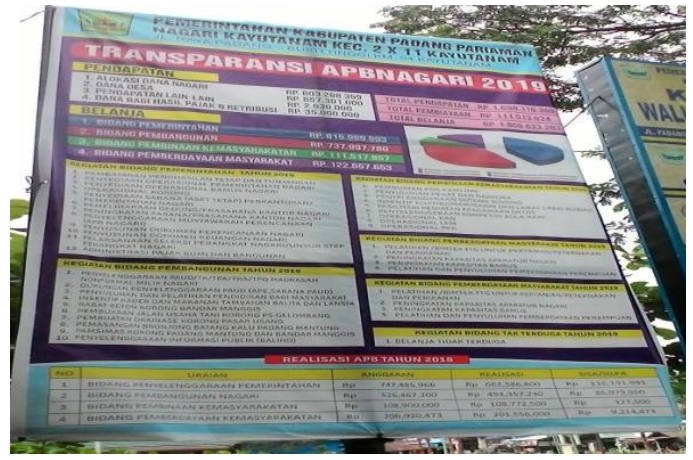




\section{Pertanggungjawaban}

Kemudian, tahap pertanggungjawaban di nagari kayu tanam pada tahun 2018 sudah cukup baik direalisasikan dan sudah cukup efisien dilihat dari laporan pertanggungjawaban, baik dalam laporan rutin atau laporan bulanan, laporan semester, dan laporan akhir semester kepada Wali Nagari, tingkat Kecamatan, dan pada tingkat Kabupaten. Laporan Realisasi Pelaksanaan APBNagari Kayu Tanam Tahun Anggaran 2018, sebagai berikut;

Tabel 2.

Laporan Realisasi Pelaksanaan APB Nagari Kayu Tanam Tahun Anggaran 2018

\begin{tabular}{|c|c|c|c|c|}
\hline NO & Uraian & Anggaran & Realisasi & Lebih Kurang \\
\hline 1 & $\begin{array}{l}\text { Pendapatan } \\
\text { Pendapatan Asli Nagari } \\
\text { Lain-lain Pendapatan Nagari Yang Sah } \\
\text { Dana Transfer } \\
\text { Dana Desa } \\
\text { Hasil Pajak dan Retribusi } \\
\text { Aloksi Dana Desa } \\
\text { Bantuan Keuangan Kabupaten }\end{array}$ & $\begin{array}{l}\mathbf{0 , 0 0} \\
0,00 \\
\mathbf{4 . 9 6 7 . 4 5 2 . 6 0 0 , 0 0} \\
752.400 .000,00 \\
60.698 .600,00 \\
1.230 .354 .000,00 \\
2.924 .000 .000,00\end{array}$ & $\begin{array}{l}\text { 9.516.157,00 } \\
9.516 .157,00 \\
\mathbf{4 . 9 7 2 . 9 6 4 . 2 5 5 , 0 0} \\
752.400 .000,00 \\
66.210 .255,00 \\
1.230 .354 .000,00 \\
2.924 .000 .000,00\end{array}$ & $\begin{array}{l}\mathbf{9 . 5 1 6 . 1 5 7 , 0 0} \\
9.516 .157,00 \\
\mathbf{5 . 5 1 1 . 6 5 5 , 0 0} \\
0,00 \\
5.511 .655,00 \\
0,00 \\
0,00\end{array}$ \\
\hline & JUMLAH PENDAPATAN & 4.967.452.600,00 & $4.982 .480 .412,00$ & $15.027 .812,00$ \\
\hline 2 & $\begin{array}{l}\text { Belanja } \\
\text { Belanja Nagari } \\
\text { Belanja Pegawai } \\
\text { Belanja Barang dan Jasa } \\
\text { Belanja Modal } \\
\end{array}$ & $\begin{array}{l}\mathbf{5 . 7 7 1 . 5 7 0 . 2 4 2 , 0 0} \\
334.172 .600,00 \\
1.604 .217 .857,00 \\
3.833 .179 .785,00\end{array}$ & $\begin{array}{l}\mathbf{5 . 0 7 1 . 2 4 9 . 6 7 7 , 0 0} \\
318.151 .744,00 \\
1.287 .920 .892,00 \\
3.465 .177 .041,00\end{array}$ & $\begin{array}{l}\text { 700. 320.565,00 } \\
16.020 .856,00 \\
316.296 .965,00 \\
368.002 .744,00\end{array}$ \\
\hline & $\begin{array}{l}\text { JUMLAH BELANJA } \\
\text { SURPLUS/DEFISIT }\end{array}$ & $\begin{array}{l}\text { 5.771.570.242,00 } \\
\text { 804.117.642,00 }\end{array}$ & $\begin{array}{l}\text { 5.071.249.677,00 } \\
\text { 88.769.265,00 }\end{array}$ & $\begin{array}{l}\text { 700. 320.565,00 } \\
\text { 715. 348. 377,00 }\end{array}$ \\
\hline 3 & $\begin{array}{l}\text { Pembiayaan } \\
\text { Penerima Pembiayaan } \\
\text { Sisa Lebih Pembiayaan Anggaran } \\
\text { Pengeluaran Pembiayaan } \\
\text { Penyertaan Modal }\end{array}$ & $\begin{array}{l}\mathbf{9 0 4 . 1 1 7 . 6 4 2 , 0 0} \\
904.117 .642,00 \\
\\
\mathbf{1 0 0 . 0 0 0 . 0 0 0 , 0 0} \\
100.000 .000,00\end{array}$ & $\begin{array}{l}\mathbf{9 0 4 . 1 1 7 . 6 4 2 , 0 0} \\
904.117 .642,00 \\
\mathbf{0 , 0 0} \\
100.000 .000,00\end{array}$ & $\begin{array}{l}\mathbf{0 , 0 0} \\
0,00 \\
\mathbf{1 0 0 . 0 0 0 . 0 0 0 , 0 0} \\
0,00\end{array}$ \\
\hline & JUMLAH PEMBIAYAAN & 804.117.642,00 & 904.117.642,00 & $100.000 .000,00$ \\
\hline & $\begin{array}{l}\text { SISA LEBIH } \quad \text { (KURANG) } \\
\text { PERHITUNGAN ANGGARAN }\end{array}$ & $\mathbf{0 , 0 0}$ & 815. 348. 377,00 & 815. 348. 377,00 \\
\hline
\end{tabular}

Sumber: Laporan Pertanggungjawaban Realiasi Pelaksanaan APB Nagari Tahun 2018

Jadi, laporan realisasi pelaksanaan APB Nagari ini sudah efektif yang dilihat dari hasil SILPA yang dihasilkan $9.8 \%$ direalisasikan di nagari kayu tanam, tetapi laporan realisasi APB Nagari tahun 2019 belum adanya kesesuaian hasil pertanggungjawaban dikarenakan masih belum selesainya laporan akhir tahunnya.
Sesuai dengan penemuan penulis di atas bahwa penggunaan aplikasi siskeudes di Nagari Kayu Tanam Kecamatan 2x11 kayu tanam sudah cukup efisien, efektif dan kesesuaian dalam pelaksanaannya, melalui tahap perencanaan, pelaksanaan, pelaporan, dan pertanggungjawaban. Berdasarkan hasil penelitian lain bahwa bentuk evaluasi keuangan desa, menurut 
Devi, Kadek Dwi Purnama (2017), bahwa laporan keuangan menggunakan PSAK No.45 masih terkendala dalam pelaksanaannya, yaitu pertama; tidak adanya pelatihan mengenai penyusunan laporan keuangan yang menggunakan PSAK No. 45, dan kedua; sumber daya manusia yang tidak mendukung, karena tidak semua yang berlatang belakang pendidikan dibidang akuntansi. Sedangkan menurut Abdullah, Muksin Hi., \& Samad, A (2019), bahwa aplikasi ini belum memberikan kontribusi yang signifikansi terhadap kinerja kepala desa selaku penyelenggaraan pemerintahan di desa. Kemudian, menurut (Vaguita, Mercya., \& Adnan, M. F. (2019), bahwa pengelolaan keuangan belum maksimal disebabkan karena sumber daya manusia yang kurang mendukung, rendahnya swadaya masyarakat, pengawasan masyarakat masih kurang, masih rendahnya partisipasi masyarakat, dan adanya perubahan anggaran pada pelaporan pertanggungjawaban.

\section{Kendala dalam Penggunaan Sistem Keuangan Desa di Nagari Kayu Tanam Kecamatan 2x11 Kayu Tanam}

\section{Adanya Kesalahan Teknis}

Adanya kesalahan teknis pada penginputan data kegiatan nagari dilakukan oleh 1 (satu) orang yaitu Kaur Perencanaan itu sendiri. Dengan adanya perubahan aturan Siskeudes pasti versi aplikasi Siskeudes ikut juga berbeda, sehingga sering terjadi perubahan dalam sub bidang dan juga pengkodean rekingnya. Misalnya, adanya kegiatan nagari seperti pembangunan irigasi nagari biasanya di versi Siskeudes yang lama masuk dalam bidang Pembangunan Nagari sekarang diversi terbaru sesuai dalam Menteri Dalam Negeri Nomor 20 Tahun 2018 termasuk pada bidang Pembinaan Nagari, hal ini juga mengakibatkan kekeliruan dan kebingungan dalam penginputan. Karena isi menu-menu dalam item kegiatan yang ada terdapat 4 (empat) bidang yaitu bidang penyelenggaraan pemerintahan, pembangunan desa, pembinaan masyarakat, dan pemberdayaan masyarakat yang belum sinergi dengan aturan Kemendagri sehingga dapat membingungkan operator ataupun kaur keuangan yang ada. Aplikasi Siskeudes tersebut memberikan kemudahan pegawai dalam mengelola keuangan nagari. Aplikasi Siskeudes ini hanya memiliki 1 (satu) master dengan 1 (satu) buah komputer yang ada disediakan tanpa menggunakan akses internet, sehingga pegawai dapat menginput menggunakan laptop masing-masing dengan memiliki program Siskeudes dan memiliki kode password melalui Sekretaris Nagari.

\section{Adanya Gangguan Lingkungan}

Aplikasi Siskeudes ini menggunakan komputer, terjadinya gangguan seperti faktor cuaca apabila hujan hal tersebut mengakibatkan listrik mati dan urusan dalam penginputan pada aplikasi tersebut menjadi terhambat karena arus listrik. Selain itu, komputer ataupun laptop yang digunakan pegawai pada umumnya sering mengalami error dalam penginputan, dan pada akhirnya masih dilakukan secara manual dalam pengelolaan keuangan nagari ini, tetapi untuk perincian keuangan nagari ini tetap menggunakan aplikasi Siskeudes tersebut sesuai dalam Perbup APB Nagari yang dimulai sejak Januari hingga bulan Maret. 


\author{
NAKHODA: JURNAL ILMU PEMERINTAHAN \\ Edisi Juli-Desember 2019 Tahun Volume: 18 Nomor: 2 \\ ISSN : 1829-5827 | E-ISSN : 2656-5277 \\ DOI : https://doi.org/10.35967/jipn \\ https://nakhoda.ejournal.unri.ac.id/index.php/JIPN
}

\section{Adanya Kelalaian Manusia}

Aplikasi Siskeudes ini dikendalikan dan dipegang oleh Sekretaris Nagari, dan dibantu oleh operator lainnya seperti Kaur Perencanaan dan Kaur Keuangan. Kegiatan yang dinput sesuai anggarannya kemudian akan diverifikasi oleh Sekretaris Nagari dan dikunci kembali program tersebut oleh Sekretaris agar memberikan keamanan dalam pengelolaan keuangan nagari. Hal tersebut tidak luput dari kesalahan pegawai dalam penginputan, terdapat kendala bagi pegawai yang masih pemula, hal ini masih ada terjadi, karena ilmu Siskeudes ini tiap tahun berbedabeda versi. Jadi, bagi pegawai pemula pasti terbatas ilmunya dan lama prosesnya dalam memahami dan mempelajari aplikasi tersebut dan perlu dilakukan pelatihan untuk pegawai pemula tersebut. Berbeda dengan pegawai yang sudah lama ataupun sudah pernah menggunakan aplikasi versi lama sebelumnya, adapun versi yang baru akan mudah disesuaikannya dengan kebutuhan yang ada diperlukan nagari tersebut, misalnya biasanya ATK dianggarkan sekitar 13 kotak, terjadi menambahan kebutuhan maka tinggal ditambahkan dalam Siskeudes, karena sudah ada diatur dalam aplikasi tersebut dan tinggal diinput.

Sesuai dengan hasil penulis di atas, ditemukan bahwa adanya tiga faktor yang menjadi kendala dalam penggunaan aplikasi siskeudes di Nagari Kayu Tanam Kecamatan 2x11 Kayutanam, yaitu; Pertama adanya kesalahan teknis dilihat dari pengelola admin dalam penginputan data, Kedua gangguan lingkungan, dilihat dari faktor internal dan eksternal, dan Ketiga kelalaian manusia, dilihat dari keahlian dari operator yang mengelola aplikasi siskeudes ini. Sedangkan dilihat dari hasil penelitiannya Sulina, G. A. T., Wahyuni, M. A., \& Kurniawan, P. S. (2017), bahwa adanya kelemahan dalam siskeudes ini, yaitu sulitnya memahami penggunaan aplikasi ini karena aplikasi ini masih baru diterapkan sehingga sulit untuk mengaplikasinnya, kurangnya pelatihan untuk pegawai dalam aplikasi Siskeudes. Kelemahan tersebut menimbulkan kendala dalam penerapan aplikasi Siskeudes diantaranya adalah sistem keuangan masih terbilang rumit bagi sebagian pegawai, kurangnya pelatihan dan terjadinya eror pada sistem. Kemudian dilihat dari penelitiannya Malahika, J. M., Karamoy, H., \& Pusung, R. J. (2018), bahwa penerapan di Desa Suwaan ini juga terdapat beberapa kendala, yaitu (1) aplikasi Siskeudes sering terjadi masalah error saat proses penginputan. (2) Masih terdapat beberapa laporan yang belum terinput ke sistem dan masih menggunakan pelaporan secara manual.

\section{KESIMPULAN}

Berdasarkan hasil penelitian dan pembahasan yang telah diuraikan di atas, maka penulis menyimpulkan bahwa aplikasi sistem keuangan desa (Siskeudes) di Nagari Kayu Tanam Kecamatan 2x11 Kayutanam sudah cukup baik dalam penggunaannya, dilihat dari aspek efisiensi, efektif, dan kesesuaian dalam aplikasi tersebut melalui tahap perencanaan dan tahap pelaksanaan, sedangkan belum efektif dan belum ada kesesuaian pada tahap pelaporan dan tahap pertanggungjawaban. Tetapi, dalam pelaksanaannya masih ada kendala yang ditemukan, diantaranya yaitu; kurangnya sumber daya manusia; pelatihan dari pihak 
kabupaten belum maksimal; terdapat keterlambatan dalam penyusunan laporan pertanggungjawaban; dan partisipasi masyarakat yang masih kurang, hal ini disebabkan karena tiga faktor, yaitu; adanya kesalahan teknis, gangguan lingkungan, dan kelalaian dari manusia dalam pemerintahan nagari limo kaum.

Diharapkan hasil penelitian ini dapat berkontribusi sebagai masukan serta sumbangan pemikiran dalam kajian Ilmu Pemerintahan khususnya Pemerintahan Nagari dan Tata Kelola Keuangan Pemerintah.

Berdasarkan hasil penelitian dan kesimpulan tersebut, maka penulis mengemukakan saran-saran sebagai berikut:

1. Perlu dilakukan perekrutan sumber daya yang kompeten pada bidang keahlian dan pengetahuan operator dalam penggunaan sistem di Kecamatan 2x11 Kayutanam.

2. Perlu pengembangan sistem dan tolak ukur dalam evaluasi sistem untuk kemudahan dan kenyamanan dalam menggunakan Siskeudes di Kecamatan 2x11 Kayutanam.

3. Perlu dilakukan pelatihan setiap versi dalam tampilan baru aplikasi Siskeudes dan memberikan pendamping operator nagari ini agar dapat mengontrol kesalahan apabila terjadi kekeliruan dalam penginputan data.

\section{DAFTAR PUSTAKA}

Darmawan, Deni. 2013. Sistem Informasi Manajemen. ed. Remaja Rosdakarya. Bandung.

Mulyadi, Deddy. 2016. Carbohydrate
Polymers Studi Kebijakan Publik Dan Pelayanan Publik

Sutabri, Tata. 2016. Sistem Informasi

Manajemen. ed. Andi Offset.

Yogyakarta

Wirawan. 2011. Evaluasi Teori Model

Standar Aplikasi Dan Profesi, Contoh

Aplikasi Evaluasi Program:

Pengembangan Sumber Daya

Manusia Program Nasional

Pemberdayaan Masyarakat (PNPM)

Mandiri Pedesaan, Kurikulum,

Perpustakaan, Dan Buku Tes. ed.

Raja Grafindo Persada. Jakarta.

\section{Jurnal}

Abdullah Muksin Hi., \& Samad, A. (2019). Pengaruh Sistem Informasi Keuangan Desa (Siskeudes) Terhadap Kinerja Pemerintah Desa (Studi Kasus Desa Tokaka, Kecamatan Gane Barat Utara, Kabupaten Halmahera Selatan )IJIS Indonesian Journal on Information System ISSN 2548-6438. IJIS-Indonesia Journal on Information System, 4(April), 69-76. https://doi.org/10.1021/jp5128578

Sari, M. A., Aini, N., Islami, A., \& Febrina, R. (2019). Aktualisasi Pertanggungjawaban Penggunaan Dana Desa Di Kabupaten Siak Tahun 2017. Nakhoda: Jurnal Ilmu Pemerintahan, 18(31), 47-53. https://doi.org/10.35967/jipn.v18i31.7 805

Sulina, G. A. T., Wahyuni, M. A., \& Kurniawan, P. S. (2017). Peranan Sistem Keuangan Desa (SISKEUDES) Terhadap Kinerja Pemerintah Desa ( Studi Kasus di Desa Kaba-kaba, Kecamatan Kediri, 
Kabupaten Tabanan ). e-Journal S1 Ak Universitas Pendidikan Ganesha. Jurnal Akuntansi, 1(2).

Dwi, K., Devi, P., Atmadja, A. T., \& Julianto, P. (2017). Evaluasi Pertanggungjawaban Laporan Keuangan Di Desa Pedawa. eJournal S1 Ak Universitas Pendidikan Ganesha. Jurnal Akuntansi, 1(45).

Puspita, D. E., Sholihin, M. R., \& Andrianti, S. R. (2019). Evaluasi Penggunaan Aplikasi Siskeudes (Sistem Keuangan Desa) Dalam Upaya Peningkatan Kualitas Akuntabilitas Keuangan Desa Tahun 2018 (Studi Kasus Pada Desa

Nogosari Kecamatan Rowo Kangkung Kabupaten Lumajang). Prosiding Seminar Nasional dan Call For Paper. 2019, 168-175.

Lengkong, V. P. K., \& Tasik, H. H. D. (2018). Evaluasi Pengelolaan Dana Desa Dengan Instrumen Dimensi Pengukuran Pengelolaan Dana Desa ( Dp2d2 ) Berdasarkan UndangUndang Nomor 6 Tahun 2014. Jurnal Manajemen Bisnis Dan Inovasi, 5(1), 15-28.

Malahika, J. M., Karamoy, H., \& Pusung, R. J. (2018). Penerapan Sistem Keuangan Desa (Siskeudes) pada Organisasi Pemerintahan Desa (Studi Kasus di Desa Suwaan Kecamatan Kalawat Kabupaten Minahasa Utara). Going Concern : Jurnal Riset Akuntansi, 14(1), 578-583. https://doi.org/10.32400/gc.13.04.215 14.2018

Novirania, Aziza. 2018. Implementasi Aplikasi Sistem Keuangan Desa (Siskeudes) di Desa Bogorejo, Kecamatan Gedong Tataan,
Kabupaten Pesawaran. Skripsi. Lampung: Universitas Lampung. Usman, Syarifuddin, \& Asrul Sani Habib. 2016. Evaluasi Kebijakan Satu Desa Satu Milliar Pemerintah Kabupaten Pulau Morotai (Studi Desa Gotalamo Kecamatan Morotai Selatan Dan Desa Bere-Bere Kec. Morotai Utara). Jurnal Ilmu Pemerintahan : Kajian Ilmu Pemerintahan dan Politik Daerah, 1 (2).

Vaguita, M., \& Adnan, M. F., \& Padang, U. N. (2019). Inhibited Factors In Management Government Finance Of Nagari : Case Study In Nagari Kamang Hilir, Kamang Magek Subdistrict, Agam Regency. JISPO: Jurnal Ilmu Sosial dan Ilmu Politik, 9(2), 256-264.

Vyara, Nadya Rizky. 2017. Evaluasi Pelaksanaan Program (CSR) PT.PLN (Persero) P3BS UPT Padang Dalam Budidaya Jamur Tiram Di Nagari Tanjung Alam Kabupaten Tanah Datar. Skripsi. Padang: Universitas Negeri Padang

Welley, M. M., Koleangan, R. A. M., \& Kawung, G. M. V. (2019). Perbandingan Sebelum Dan Sesudah Menggunakan Aplikasi Siskeudes Dalam Pengelolaan Keuangan Desa Dan Dampaknya Terhadap Pembangunan Desa. Jurnal Pembangunan Ekonomi Dan Keuangan Daerah, 19(8), 1-16. https://doi.org/10.35794/jpekd.23431. 19.8.2018

\section{Peraturan Perundang - Undangan}

UUD NRI Tahun 1945 Pasal 18 B Ayat (2)

Pemerintah Republik Indonesia. 2014. "Permendagri Nomor 113 Tahun 
1. NAKHODA:

JURNAL

ILMU PEMERINTAHAN
NAKHODA: JURNAL ILMU PEMERINTAHAN

Edisi Juli-Desember 2019 Tahun Volume: 18 Nomor: 2

ISSN : 1829-5827 | E-ISSN : 2656-5277

DOI : https://doi.org/10.35967/jipn

https://nakhoda.ejournal.unri.ac.id/index.php/JIPN

2014." Respiration Physiology.

Peraturan Menteri Dalam Negeri Republik

Indonesia Nomor 20 Tahun 2018

Tentang Pengelolaan Keuangan Desa.

Undang-Undang No 6 Tahun 2014

Tentang Desa 